Plant Tissue Cult. \& Biotech. 21(1): 45-52, 2011 (June)

$\overline{\text { PTC\&B }}$

\title{
Studies on High Frequency Shoot Regeneration in Sesame (Sesamum indicum L.)
}

\section{Bangaramma S. Wadeyar and R. Lokesha*}

Plant Tissue Culture and Molecular Laboratory, Department of Genetics and Plant Breeding, University of Agricultural Sciences, Raichur-583 102, India

Key words: Sesamum indicum, Hypocotyl, High frequency, Shoot regeneration

\begin{abstract}
High frequency shoot regeneration was attempted in sesame (Sesamum indicum L. Pedaliaceae), using five genotypes/varieties viz. Tumkur and Gulbarga Locals (land races), W-II, E-8 and DS-1 (varieties). The hypocotyl-derived callus obtained through direct seeding method was placed on MS with five different treatments viz. pre-culture of callus on high sucrose (6-9\%) for two weeks and transferring on to plain MS with 3\% sucrose, MS with variable concentrations of TDZ alone, MS with constant TDZ and variable concentrations of BA and IAA, MS with variable concentrations of $\mathrm{BA}$ and IAA without TDZ, MS with ABA and $\mathrm{AgNO}_{3}$ and $\mathrm{MS}$ with $\mathrm{BAP}, \mathrm{NAA}$ and $\mathrm{AgNO}_{3}$. Highest frequency of cent per cent shoot regeneration was initiated in variety DS-1on MS containing NAA $2.5 \mathrm{mg} / \mathrm{l}$, BAP $3.5 \mathrm{mg} / \mathrm{l}$ and $20 \mu \mathrm{M} \mathrm{AgNO} 3$ with 2.50 mean shoots/callus followed by $91.6 \%$ in variety W-II on MS containing $25 \mu \mathrm{M}$ TDZ with 2.20 mean shoots/callus. The other treatments had poor shoot regeneration response. The results have been discussed in the light of sesame improvement through biotechnological ways.
\end{abstract}

\section{Introduction}

Advances in plant tissue culture and other innovations in biotechnology have provided opportunities to plant breeders for creating a wide range of useful genetic variability and increased the precision and efficiency of selecting desirable genotypes. In particular, in vitro methods are being used progressively more as an adjunct to traditional breeding method for genetic improvement of crops. Sesame (Sesamum indicum L.) is the oldest oil seed crop known to man (Brar and Ahuja 1979) and believed to have originated from South-Western Africa, nicked as "Queen of oil crops", owing to excellent oil stability due to the presence of natural antioxidants such as sesamolin, sesamin, sesamol and alfatocopherol (Brar and Ahuja 1979). Genetic improvement of sesame through

"Corresponding author: <rlok123@rediffmail.com> 
conventional breeding methods is not rapid unlike other crops (Sardana 1998). Recent advances in tissue culture techniques offer an immense promise for sesame improvement yet it has remained unachievable. The successful application of these techniques depends on the callusing ability and regeneration of shoots; the former has been achieved by several workers while the latter, undeniably is considered to be a bottleneck (Rao et al. 1997, Taskin and Turgurt 1997, Kim 2001 and Kariyllappa 2003, Kariyallappa et al. 2003, Shashidhara 2005.

Globally, the best achieved in vitro shoot regeneration in sesame is placed up to $46 \%$ (Japan) and up to $66 \%$ in India (Shashidhara 2005). However, Seo et al. (2006) reported high regeneration ability of de-embryonated cotyledon explants via adventitious shoot formation. In India, the shoot regeneration has been very low $(<2 \%)$. Hence, it was felt necessary to enhance shoot regeneration of indigenous sesame genotypes which are land races/varieties but popular at farmer's level. This could become a crucial breakthrough to further advance the genetic improvement of sesame through biotechnological ways like transgenic development or in vitro cell lines selection that are resistant to biotic and abiotic stresses. Hence, an attempt was made to achieve high frequency regeneration of shoots via callus in sesame. The results have been discussed in the light of sesame improvement through biotechnological ways particularly in vitro cell line selections.

\section{Materials and Methods}

Five genotypes/varieties of Sesamum indicum were used for study viz. Tumkur Local (TL) and Gulbarga local white (GLW): the two land races; Western-II (W-II) (released variety from Rajasthan which is moderately tolerant to Alternaria blight and Phyllody), E-8 (white seeded, nationally released variety and most widely grown but susceptible to Alternaria blight and phyllody) and Dharwad Selection-1 (DS-1) (a white seeded variety released from UAS Dharwad, susceptible to Alternaria, phyllody and powdery mildew but resistant to Cerospora leaf spot. (Prakash 2001).

The surface sterilized seeds with $0.05 \% \mathrm{HgCl}_{2}$ were directly inoculated on to MS supplemented with the growth regulators (NAA $0.5 \mathrm{mg} / \mathrm{l}$, BAP $1.5 \mathrm{mg} / \mathrm{l}$ and $\mathrm{Kn} 1.5 \mathrm{mg} / \mathrm{l}$ ) and incubated in the dark and transferred to continuous illuminating light at 1,500 lux in culture room temperature maintained at $27^{\circ} \mathrm{C}$ as per the direct seeding method (Shashidhara 2005 and Lokesha et al. 2007). Callus induction was achieved within 15 - 17 days from different explants. The callus of hypocotyls region was separated and used for shoot induction studies. Thirtyday-old callus were subcultured on MS supplemented with $0.5 \mathrm{mg} / \mathrm{l} \mathrm{NAA}, 1.5$ $\mathrm{mg} / \mathrm{l} \mathrm{Kn}$ and $1.5 \mathrm{mg} / \mathrm{l} \mathrm{BAP}$. Every fortnight, the callus was subcultured. Light green, healthy and moderately compact callus, sub-cultured for two cycles, was 
taken as small pieces of $1.5 \mathrm{~cm}^{3}$ and were inoculated on to MS supplemented with different treatment details viz. (i) pre-culture of callus on high sucrose (6 9\%) for two weeks and transferring on to plain MS with 3\% sucrose (Seo et al. 2007), (ii) MS with variable concentrations of TDZ alone (Ahn et al. 2006), (iii) MS with constant TDZ of $25 \mathrm{uM} / 1$ with variable concentrations of BA and IAA (Ahn et al. 2006), (iv) MS with fixed concentrations of BAP and IAA (Kariyallappa 2003, Shashidhara 2005), (v) MS with fixed concentration of $\mathrm{ABA}+\mathrm{AgNO}_{3}$ (Shashidhara 2005) and (vi) MS with fixed concentrations of BAP + NAA + $\mathrm{AgNO}_{3}$ (Shashidhara 2005, Seo et al. 2007). Four callus pieces were inoculated per flask or bottles and were replicated three times for each concentration. All the flasks and bottles were incubated to 55 - 65 days for shoot regeneration.

\section{Results and Discussion}

DS-1 recorded $100 \%$ shoot regeneration with highest mean number of shots (2.50) per callus on MS with NAA $2.5 \mathrm{mg}$, BAP $3.5 \mathrm{mg} / \mathrm{l}$ and $20 \mu \mathrm{M} \mathrm{AgNO}_{3}$ followed by $91.6 \%$ by WII with 2.20 mean shoot number per callus on MS supplemented with $25 \mu \mathrm{M}$ TDZ (Tables 1 and 2). DS-1 recorded $83.30 \%$ shoot regeneration with 2.00 shoots per callus on MS supplemented with TDZ $(25 \mu \mathrm{M})$ and $3 \mu \mathrm{M}$ IAA (Table 3). Both DS-1 and WII recorded 75\% shoot regeneration (DS-1on MS with fixed concentrations of BAP $(22 \mu \mathrm{M})$, IAA $(6 \mu \mathrm{M})$ and TDZ $(25$ $\mu \mathrm{M})$ (Table 4) and TDZ $(25 \mu \mathrm{M})$ in addition to $2 \mu \mathrm{M}$ IAA (Table 3) and WII on MS with $20 \mu \mathrm{M}$ TDZ (Table 3). The other combinations were inferior to earlier attempts made by Shashidhara (2005).

DS-1 has better shoot regeneration potentiality than other genotypes irrespective of treatment combinations (Fig. 1), whilst GLW had very poor shoot regeneration ability. It was interesting that TDZ alone evoked good regeneration ability in all the genotypes. DS-1 had highest regeneration with TDZ. WII had almost equal regeneration ability with or without TDZ (Fig. 2). GLW recorded very poor shoot regeneration when TDZ was absent.

Shoot regeneration is a vital step in tissue culture attempts in sesame. Indeed, it is found that the shoot induction via callus in sesame crop is a bottleneck (Taskin and Turgut 1997, Kim 2001 and Kariyallappa 2003). Explants, genotypes and growth regulators are critical factors for shoot organogenesis and somatic embryogenesis (Venkatachalam et al. 1999). A variety of explants were used for organogenesis and regeneration but hypocotyls were found better followed by cotyledon. There are several reports of regeneration obtained from hypocotyls explants either from root or shoot or both (Lee et al. 1988; Shi and Cai 1989, Batra et al. 1991, Rao and Vaidyanath 1997, Kim 2001). 
Table 1. Shoot regeneration on MS with constant NAA $(2.5 \mathrm{mg} / \mathrm{l}), \mathrm{BAP}(3.5 \mathrm{mg} / \mathrm{l})$ and $\mathrm{AgNO}_{3}$ $(20 \mu \mathrm{M}) / 1$.

\begin{tabular}{ccccc}
\hline Genotypes & $\begin{array}{c}\text { No. of callus } \\
\text { inoculated }\end{array}$ & $\begin{array}{c}\text { No. of callus } \\
\text { responded }\end{array}$ & $\begin{array}{c}\text { Shoot } \\
\text { regeneration \% }\end{array}$ & $\begin{array}{c}\text { Mean No. of } \\
\text { shoots per callus }\end{array}$ \\
\hline GLW & 12 & 03 & 25.0 & 1.66 \\
DS I & $\mathbf{1 2}$ & $\mathbf{1 2}$ & $\mathbf{1 0 0 . 0}$ & $\mathbf{2 . 5 0}$ \\
E 8 & 12 & 05 & 41.6 & 1.60 \\
W II & 12 & 07 & 58.0 & 1.70 \\
TL & 12 & 06 & 50.0 & 1.80 \\
Over all mean & & & 54.92 & 1.85 \\
\hline
\end{tabular}

Table 2. Shoot regeneration on MS with three concentrations of TDZ alone.

\begin{tabular}{cccccc}
\hline Genotypes & $\begin{array}{c}\text { TDZ conc. } \\
(\mu \mathrm{M})\end{array}$ & $\begin{array}{c}\text { No. of callus } \\
\text { inoculated }\end{array}$ & $\begin{array}{c}\text { No. of callus } \\
\text { responded }\end{array}$ & $\begin{array}{c}\text { Shoot } \\
\text { regeneration } \\
(\%)\end{array}$ & $\begin{array}{c}\text { Mean No. } \\
\text { of shoots } \\
\text { per callus }\end{array}$ \\
\hline \multirow{3}{*}{ GLW } & 15 & 12 & 0 & 00.0 & 0.00 \\
& 20 & 12 & 0 & 00.0 & 0.00 \\
DS I & 25 & 12 & 0 & 00.0 & 0.00 \\
& 15 & 12 & 2 & 16.6 & 1.50 \\
E 8 & 20 & 12 & 3 & 25.0 & 2.00 \\
& 25 & 12 & 3 & 25.0 & 1.60 \\
& 15 & 12 & 1 & 08.3 & 1.00 \\
W II & 20 & 12 & 2 & 16.6 & 1.50 \\
& 25 & 12 & 2 & 16.6 & 1.50 \\
& 15 & 12 & 6 & 50.0 & 2.10 \\
TL & $\mathbf{2 0}$ & $\mathbf{1 2}$ & $\mathbf{9}$ & $\mathbf{7 5 . 0 0}$ & $\mathbf{2 . 1 0}$ \\
& $\mathbf{2 5}$ & $\mathbf{1 2}$ & $\mathbf{1 1}$ & $\mathbf{9 1 . 6}$ & $\mathbf{2 . 2 0}$ \\
Over all mean & 15 & 12 & 2 & 16.6 & 2.00 \\
& 20 & 12 & 3 & 25.0 & 1.60 \\
& 25 & 12 & 2 & 16.6 & 1.50 \\
\end{tabular}

(Adopted from Ahn et al. 2006)

Table 3. Shoot regeneration on MS with constant BAP $(22 \mu \mathrm{M})$, IAA $(6 \mu \mathrm{M})$ and TDZ $(25 \mu \mathrm{M})$.

\begin{tabular}{ccccc}
\hline Varieties & $\begin{array}{c}\text { No. of callus } \\
\text { inoculated }\end{array}$ & $\begin{array}{c}\text { No. of callus } \\
\text { responded }\end{array}$ & $\begin{array}{c}\text { Shoot regeneration } \\
\%\end{array}$ & $\begin{array}{c}\text { Mean no. of shoots } \\
\text { per callus }\end{array}$ \\
\hline GLW & 12 & 3 & 25.00 & 2.00 \\
DS I & $\mathbf{1 2}$ & $\mathbf{9}$ & $\mathbf{7 5 . 0 0}$ & $\mathbf{1 . 7 8}$ \\
E 8 & 12 & 7 & 58.00 & 1.80 \\
W II & 12 & 6 & 50.00 & 1.60 \\
TL & 12 & 5 & 41.60 & 2.00 \\
& & Over all mean & 49.92 & 1.84 \\
\hline
\end{tabular}


The highest percentage of shoot regeneration was observed from hypocotylderived callus on MS with NAA $2.5 \mathrm{mg} / \mathrm{l}$, BAP $3.5 \mathrm{mg} / \mathrm{l}$ and $20 \mu \mathrm{M} \mathrm{AgNO}{ }_{3}$ with $100 \%$ shoot formation in variety DS- 1 followed by $91.6 \%$ in variety W II. It was observed on MS containing TDZ $25 \mu \mathrm{M}$ and $83.3 \%$ in MS containing $25 \mu \mathrm{M}$ TDZ and $3 \mu \mathrm{M}$ IAA in variety DS-1. The similar result has been reported in Gujarat Till-II (66.66\%) from hypocotyls derived callus on MS supplemented with NAA @ $2.2 \mathrm{mg} / \mathrm{l}$, BAP @ $3.3 \mathrm{mg} / \mathrm{l}$ and AgNo3@ $20 \mu \mathrm{M}$ (Shashidhara 2005). These results are in agreement with Taskin and Turgut (1997), Kim (2001) and Kariyallappa (2003) and Shashidhara (2005).

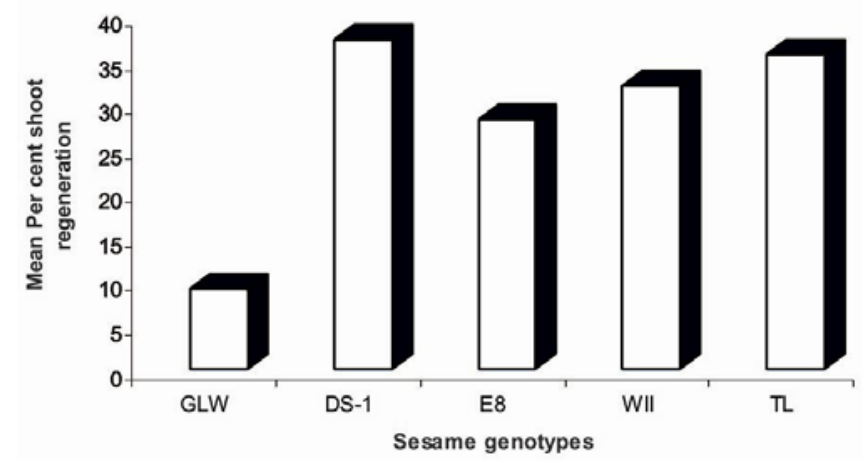

Fig. 1. Performance of different sesame genotypes across different treatment combinations.

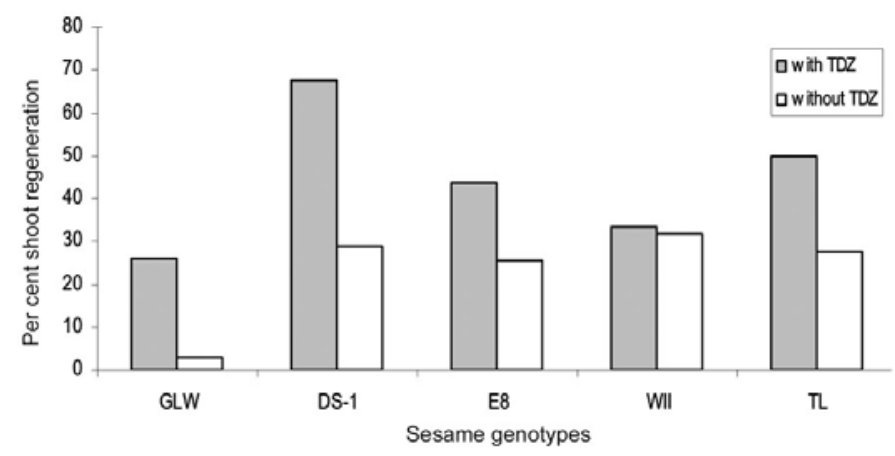

Fig. 2. Shoot regeneration of sesame genotypes on MS with and without TDZ.

TDZ (Thidiazuran), a cytokinin-a synthetic phenylurea, is considered to be one of the most active cytokinins for shoot induction in plant tissue culture (Huetteman and Preece 1993 and Murthy et al. 1998) and known to induce shoot regeneration from different explants of many recalcitrant species (Thomas and Puthur 2004). Several reports suggested that TDZ results in shoot regeneration better than other cytokinins (Thomas 2003). TDZ-induced morphogenesis 
Table 4. Shoot regeneration on MS with constant TDZ $(25 \mu \mathrm{M})$ with variable concentrations of IAA.

\begin{tabular}{cccccc}
\hline Genotypes & $\begin{array}{c}\text { IAA conc. } \\
(\mu \mathrm{M})\end{array}$ & $\begin{array}{c}\text { No. of } \\
\text { callus } \\
\text { inoculated }\end{array}$ & $\begin{array}{c}\text { No. of callus } \\
\text { responded }\end{array}$ & $\begin{array}{c}\text { Shoot } \\
\text { regeneration } \\
(\%)\end{array}$ & $\begin{array}{c}\text { Mean No. of } \\
\text { shoots per } \\
\text { callus }\end{array}$ \\
\hline \multirow{2}{*}{ GLW } & 2 & 12 & 4 & 33.00 & 1.50 \\
& 3 & 12 & 5 & 41.60 & 1.60 \\
DS I & $\mathbf{2}$ & $\mathbf{1 2}$ & $\mathbf{9}$ & 75.00 & $\mathbf{1 . 7 8}$ \\
& $\mathbf{3}$ & $\mathbf{1 2}$ & $\mathbf{1 0}$ & $\mathbf{8 3 . 3 0}$ & $\mathbf{2 . 0 0}$ \\
E 8 & 2 & 12 & 6 & 50.00 & 1.80 \\
& 3 & 12 & 7 & 58.00 & 1.50 \\
W II & 2 & 12 & 5 & 41.60 & 1.60 \\
& 3 & 12 & 4 & 33.00 & 0.75 \\
TL & 2 & 12 & 7 & 58.00 & 1.80 \\
Over all mean & 3 & 12 & 6 & 50.00 & 1.60 \\
\hline
\end{tabular}

Table 5. Shoot regeneration on MS with two concentrations (15 and $20 \mu \mathrm{M})$ of TDZ with two concentrations $(2$ and $3 \mu \mathrm{M})$ of IAA.

\begin{tabular}{|c|c|c|c|c|c|}
\hline \multicolumn{6}{|c|}{$15 \mu \mathrm{M}$ TDZ } \\
\hline Genotypes & $\begin{array}{l}\text { IAA conc. } \\
\quad(\mu \mathrm{M})\end{array}$ & $\begin{array}{c}\text { No. of } \\
\text { callus } \\
\text { inoculated }\end{array}$ & $\begin{array}{c}\text { No. of } \\
\text { callus } \\
\text { responded }\end{array}$ & $\begin{array}{c}\text { Shoot } \\
\text { regeneration } \\
\% \\
\end{array}$ & $\begin{array}{l}\text { Mean No. } \\
\text { of shoots } \\
\text { per callus }\end{array}$ \\
\hline \multirow{2}{*}{ GLW } & 2 & 12 & 1 & 08.3 & 1.00 \\
\hline & 3 & 12 & 2 & 16.6 & 1.00 \\
\hline \multirow{2}{*}{ DS I } & 2 & 12 & 6 & 50.0 & 2.00 \\
\hline & 3 & 12 & 8 & 66.6 & 1.60 \\
\hline \multirow{2}{*}{ E 8} & 2 & 12 & 3 & 25.0 & 1.60 \\
\hline & 3 & 12 & 4 & 33.0 & 1.70 \\
\hline \multirow{2}{*}{ W II } & 2 & 12 & 2 & 16.6 & 1.00 \\
\hline & 3 & 12 & 3 & 25.0 & 2.00 \\
\hline \multirow{2}{*}{ TL } & 2 & 12 & 5 & 41.6 & 2.20 \\
\hline & 3 & 12 & 6 & 50.0 & 1.80 \\
\hline Over all mean & & & & 28.3 & 1.56 \\
\hline \multicolumn{6}{|c|}{$20 \mu \mathrm{M}$ TDZ } \\
\hline \multirow{2}{*}{ GLW } & 2 & 12 & 2 & 25.00 & 1.0 \\
\hline & 3 & 12 & 4 & 33.00 & 1.00 \\
\hline \multirow{2}{*}{ DS I } & 2 & 12 & 7 & 58.00 & 2.0 \\
\hline & 3 & 12 & 8 & 66.60 & 1.80 \\
\hline \multirow{2}{*}{ E 8} & 2 & 12 & 4 & 33.00 & 2.0 \\
\hline & 3 & 12 & 6 & 50.00 & 1.80 \\
\hline \multirow{2}{*}{ W II } & 2 & 12 & 3 & 25.00 & 1.3 \\
\hline & 3 & 12 & 5 & 41.10 & 1.80 \\
\hline \multirow{2}{*}{ TL } & 2 & 12 & 6 & 50.00 & 2.0 \\
\hline & 3 & 12 & 7 & 58.00 & 2.00 \\
\hline Over all mean & & & & 28.30 & 1.56 \\
\hline
\end{tabular}


Table 6. Shoot regeneration on MS with constant concentration of BAP $(23 \mu \mathrm{M})$ with variable concentrations of IAA.

\begin{tabular}{lccccc}
\hline Genotypes & $\begin{array}{c}\text { IAA Conc. } \\
(\mu \mathrm{M})\end{array}$ & $\begin{array}{c}\text { No. of callus } \\
\text { inoculated }\end{array}$ & $\begin{array}{c}\text { No. of } \\
\text { callus } \\
\text { responded }\end{array}$ & $\begin{array}{c}\text { Shoot } \\
\text { regeneration } \\
(\%)\end{array}$ & $\begin{array}{c}\text { Mean No. of } \\
\text { shoots per } \\
\text { callus }\end{array}$ \\
\hline GLW & 5 & 12 & 0 & 00.00 & 0.00 \\
& 6 & 12 & 0 & 00.00 & 0.00 \\
DS I & 7 & 12 & 0 & 00.00 & 0.00 \\
& 5 & 12 & 3 & 25.00 & 2.00 \\
E 8 & 6 & 12 & 4 & 33.00 & 2.00 \\
& 7 & 12 & 5 & 41.60 & 2.00 \\
& 5 & 12 & 4 & 33.00 & 1.75 \\
W II & 6 & 12 & 5 & 41.60 & 1.80 \\
& 7 & 12 & 6 & 50.00 & 1.50 \\
TL & 5 & 12 & 5 & 41.60 & 1.80 \\
& 6 & 12 & 3 & 25.00 & 1.60 \\
& 7 & 12 & 4 & 33.00 & 2.00 \\
Over all mean & 5 & 12 & 2 & 16.60 & 2.00 \\
\hline
\end{tabular}

probably depends on the level of endogenous growth regulators and TDZ modulates endogenous auxin level (Murthy et al. 1995 and Hutchinson and Saxena 1996). Multiple high frequency shoot induction in several crops by TDZ is known (Kumar et al. 2003). However, the report of its usage in Sesame crop is scares except (Shashidhara 2005).

\section{References}

Ahn Y, Vang L, Mckeon TA and Chen GQ (2006) High-frequency plant regeneration through adventitious shoot formation in castor (Ricinus communis L.). In Vitro Cellul. Develop. Bio. Pl. 43: 9-15.

Batra A, Mukta-Dhingra, Renu-Gogna, Batra A, Dhingra-M and Gogna R (1991) Induction of diversified root system in vitro culture of Sesamum indicum L. J. Phytol. Res. 4(1): 93-97.

Brar GS and Ahuja KL (1979) Sesame: its culture, genetics, breeding and biochemistry. In: Malik, C.P. (Ed.). Ann. Rev. Pl. Sci. Kalyani publishers, New Delhi, pp. 245-315.

Huetteman CA and Preece JE (1993) Thidiazuron: a potent cytokinin for woody plant tissue culture. Pl. Cell Tiss. Org. Cult. 33: 105-119.

Kariyallappa DK (2003) In vitro regeneration and cell line selection for Alternaria resistant callus in sesame (Sesamum indicum L.). M.Sc. Thesis, Uni. Agric. Sci. Dharwad.

Kariyallappa DK, Lokesha R, Naik MK and Treertha Prasad D (2003) Breeding for Alternaria blight resistant in sesame - classical v/s biotechnological approaches. National Sem. on Adv. in Gen. and Pl. Breed. Impact of DNA Revolution. Uni. Agric. Sci. Dharwad. pp. 157-158. 
Kim Young Hee (2001) Effects of BA, NAA, 2-4,D and $\mathrm{AgNO}_{3}$ treatments on the callus induction and shoot regeneration from hypocotyls and cotyledon of Sesame (Sesamum indicum L.) J. The Korean Soc. Hortic Sci. 42(1): 70-74.

Kumar P, Srivastava GC, Panwar JDS, Chandra R and Raghuveer P (2003) Efficiency of thidiazuran on in vitro shoot regeneration from cotelydonary node explants in mungbean. Indian J. P1. Physiol. 8(4): 398-401.

Lee SY, Kim HS and Lee YT (1988) Effects of growth regulators on callus induction and organ regeneration from seedling explant sources of sesame (S. indicum L.) cultivars. Res. Rep. Rural Develop. Admini. Biotechnol. Korea Republic, 30(1): 69-73.

Lokesha R, Shashidhara N and Janagoudar BS (2007) callus induction and plant regeneration in sesame (Sesamum indicum L.) through direct seedling. J. Pl. Cell Biotechnol. Mol. Biol. 8(1\&2): 85-88.

Murthy BNS, Murch SJ and Saxena PK (1998) Thidiazuron: a potential regulator of in vitro plant morphogenesis. In vitro Cell. Develop. Pl. Biol. 34: 267-275.

Prakash R Chavan (2001) Phenotypic and molecular characterization of wild, land races and cultivated types of sesame. M.Sc. Thesis, Uni. Agric. Sci. Dharwad.

Rao RK and Vaidyanath K (1997) Somatic embryogenesis and regeneration from different explants of Sesamum indicum L. National Symp. Commercial aspects of Pl. Tiss. Cult. Mole. Bio. and Medici. Pl. Biotechnol. Jamia Hamdard, New Delhi.

Sardana J (1998) In vitro studies on growth and morphogenesis of some oil containing plant species through tissue culture. Ph.D Thesis, Univ. Agric. Sci. Rajasthan, Jaipur

Seo HY, Kim YJ, Park TI, Kim HS, Yun SJ, Park KH, Oh MK, Choi MY, Paik CH, Lee YS and Choi YE (2007) High-frequency plant regeneration via adventitious shoot formation from deembryonated cotyledon explants of Sesamum indicum L. In Vitro Cellular and Develop. Biol. Pl. 43(3): 209-214.

Shashidhara N (2005) Shoot regeneration via rapid method of callusing in sesame (Sesamum indicum L.). M.Sc. Thesis, Univ. Agric. Sci. Dharwad.

Shi-Shuwen and Cai-Miing (1989) Effects of inducing factors on pollen callus formation of in vitro cultured anthers of sesame (Sesamum indicum L.). Oil Crops of China. 1: 45-49.

Taskin KM and Turgut K (1997) In vitro regeneration of sesame. Turkish J. Bot. 21(1): 1518.

Thomas DT (2003) Thidiazuron induced multiple shoot induction and plant regeneration from cotyledonary explants of mulberry. Biol. Pl. 46: 529-533.

Thomas DT and Puthur JS (2004) Thidiazuron induced high frequency shoot organogenesis in callus from Kigelia pinnata L. Bot. Bull. Acad. Soc. 45: 307-313.

Venkatachalam P, Geeta N, Rao KS, Jayabalan N and Saravanababu S (1999) BAP regulated direct shoot organogenesis from cultured seedling explants of Ground nut (Arachis hypogaea L.). Indian J. Experi. Biol. 37: 807-812. 